\title{
KARAKTERISTIK DEWAN KOMISARIS, KOMITE DAN PENGUNGKAPAN RISIKO PERUSAHAAN
}

\author{
Andre Falendro, Faisal*), Imam Ghozali \\ Program Magister Akuntansi \\ Fakultas Ekonomika dan Bisnis Universitas Diponegoro \\ Jl. Prof. Soedarto, Tembalang, Kota Semarang, Jawa Tengah, Indonesia. \\ Email Koresponden: fe_faisal@yahoo.co.id
}

Diterima:

24 September 2018

Direvisi:

11 Oktober 2018

Disetujui:

24 Oktober 2018

Artikel ini tersedia di website: http:// ejournal.umm.ac.id/ index.php/jrak

\section{Abstract}

This study examines the influences of board of commissioner and committee characteristics on the extent of enterprise risk management disclosure. The sample consists of 168 non-financial companies listed on Indonesia Stock Exchange for period of 2014-2016. A risk disclosure index is used to measure the extent of such disclosure. The results show that the presence risk management committee has a significant effect on the extent of risk disclosure. However, other board and committee characteristics doesn't have significant influence on risk disclosure. The result of this suggests that corporate governance mechanisms, specifically board and audit committee have not fully explained their role in enhancing transparency, especially in communicating corporate risks.

Keywords: corporate governance, board of commissioneer, Enterprise Risk Management, risk management committee, disclosure.

\section{PENDAHULUAN}

Dalam dekade terakhir, runtuhnya perusahaan besar dan krisis keuangan global telah menyebabkan ketidakstabilan dan kekhawatiran luas di pasar keuangan dunia. Salah satu faktor yang diduga menyebabkan permasalahan tersebut adalah praktik pengungkapan perusahaan yang tidak akurat dan tidak memadai tentang praktik tata kelola, terutama yang berkaitan dengan kegiatan manajemen risiko (Ntim et al., 2013; Chang et al., 2015). Hal tersebut berdampak pada kemampuan investor untuk menilai kinerja dan risiko perusahaan publik secara keseluruhan (Buckby et al., 2015). Pengungkapan risiko merupakan salah satu cara perusahaan untuk berkomunikasi dengan para pemangku kepentingannya (Beretta dan Bozzolan, 2004). Melalui pengungkapan risiko, perusahaan dapat memberikan informasi, khususnya informasi mengenai risiko yang terjadi di perusahaan (Taylor et al., 2010). Luas pengungkapan risiko menunjukkan kemampuan perusahaan dalam mengelola risiko dan memberikan informasi yang dibutuhkan oleh para pemangku kepentingan (Abraham dan Cox, 2007; Amran et al., 2009; Abraham dan Shrives, 2014). Selain itu pengungkapan risiko juga dapat mengurangi ketidakpastian arus kas masa depan perusahaan (Al-Maghzom et al., 2016) dan sebagai sarana untuk melindungi pemegang saham (Htay et al., 2011).

Pemerintah Indonesia memiliki keseriusan dalam mengelola risiko yang terjadi dalam perusahaan (Achmad et al., 2017). Salah satu bentuk keseriusan pemerintah adalah dengan mengeluarkan peraturan mengenai pengungkapan risiko yang tertuang dalam peraturan pengungkapan informasi risiko dalam Pernyataan Standar Akuntansi Keuangan 60/PSAK 60 (revisi 2014). Selain itu, Otorisasi Jasa Keuangan (OJK) juga meluncurkan peraturan manajemen risiko
Doi: 10.22219/ jrak.v8i2.31

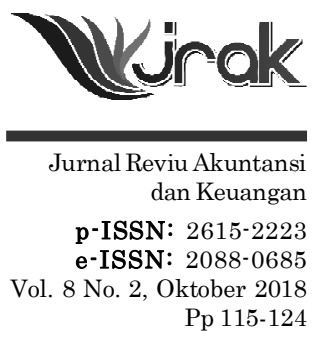


Karakteristik Dewan Komisaris...

116 tentang penerapan manajemen risiko bagi bank umum, yaitu peraturan Nomor 17 Tahun 2014, Nomor 1 Tahun 2015 dan Nomor 18 Tahun 2016. Adanya regulasiregulasi tersebut menunjukkan adanya reformasi dalam praktik tata kelola perusahaan. Sebagaimana yang dinyatakan oleh Hernandez Madrigal et al (2015) bahwa praktik pengungkapan risiko merupakan bagian penting dari reformasi tata kelola perusahaan.

Penelitian-penelitian sebelumnya menunjukkan hasil yang tidak konsisten terkait pengaruh struktur tata kelola perusahaan terhadap pengungkapan risiko (Samaha et al., 2015), khususnya karakteristik dewan komisaris. Achmad et al. (2017) menyatakan bahwa komisaris yang independen dapat memberikan kontribusi yang substansial untuk keputusan penting perusahaan. Selain independensi, karakteristik penting dari dewan komisaris adalah tingkat kompetensi atau keahlian profesional dan latar belakang pendidikan formal anggota dewan komisaris merupakan variabel yang dapat mempengaruhi kemampuan dewan komisaris dalam mengambil keputusan dan menjalankan fungsinya dalam perusahaan (Gray et al., 2014). Namun, penelitian mereka gagal memberikan bukti empiris yang signifikan terkait pengaruh positif independensi dan tingkat kompetensi dewan komisaris terhadap pengungkapan risiko perusahaan. Sebaliknya, hasil penelitian Htay et al. (2011) menemukan bahwa komisaris independen berpengaruh terhadap pengungkapan risiko perusahaan. Semakin tinggi tingkat keahlian profesional dewan komisaris dalam bidang hukum, ekonomi dan bisnis maka semakin baik kemampuan mereka untuk mengidentifikasi masalah risiko yang relevan yang spesifik bagi perusahaan (Buckby et al., 2015).

Peran pengawasan pada komite audit independen sebelumnya telah diidentifikasi sebagai mekanisme pemantauan yang efektif, yang membantu dewan komisaris dalam melaksanakan pengendalian dan pengawasan. Buckby et al. (2015) memberikan bukti empiris bahwa keahlian komite audit berpengaruh positif terhadap keluasan pengungkapan risiko perusahaan. Namun, hasil penelitian AlMaghzom et al. (2016) dan Zhang et al. (2013) menunjukkan bahwa keberadaan komite audit tidak memberikan efek yang signifikan terhadap tingkat pengungkapan risiko. Selain komite audit, keberadaan komite manajemen risiko (KMR) juga merupakan bagian dari organ dewan komisaris yang berfungsi mengawasi dan mengendalikan terjadinya potensi risiko perusahaan. Al-Hadi et al. (2016) menemukan bahwa keberadaan komite manajemen risiko dalam perusahaan memberikan pengaruh yang positif terhadap pengungkapan risiko pasar.

Adanya inkonsistensi hasil penelitian sebelumnya memotivasi peneliti untuk menguji pengaruh karateristik dewan komisaris dan komite terhadap keluasan pengungkapan risiko perusahaan publik di Indonesia. Secara khusus, penelitian ini bertujuan untuk menguji bagaimana pengaruh dewan komisaris independen, keahlian dewan komisaris, keberadaan komite audit, keahlian komite audit, dan keberadaan komite manajemen risiko terhadap pengungkapan risiko perusahaan. Penelitian ini berkontribusi dalam pengembangan literatur tata kelola perusahaan dan pengungkapan risiko dengan memberikan bukti emprisi pengaruh karateristik dewan komisaris dan komite terhadap pengungkapan risiko. Beberapa penelitian sebelumnya yang menguji determinan pengungkapan risiko hanya berfokus pada keberadaan dewan komisaris dan komite audit. Penelitian ini mempertimbangkan karateristik lain dari dewan komisaris, yaitu keberadaan komite manajemen risiko yang belum banyak diteliti oleh peneliti sebelumnya, khususnya di Indonesia.

Teori keagenan (agency theory) menjelaskan hubungan satu pihak atau lebih (principal) yang telah sepakat dengan pihak lain (agent) untuk memberikan jasa, wewenang terhadap agen untuk mengambil keputusan (Jensen dan Meckling, 1976). Menurut Jensen dan Meckling (1976), hubungan keagenan yang terdapat di perusahaan berbentuk kontrak antara pemilik (principal) dan manajer (agent) dalam mengelola penggunaan dan pengendalian sumberdaya perusahaan. Kontrak tersebut mengatur hak dan kewajiban pihak dengan tetap memperhitungkan manfaat secara keseluruhan (Watts dan Zimmerman, 1983). Adanya kontrak 
tersebut dapat memicu konflik (Jensen dan Meckling, 1976; Watts dan Zimmerman, 1983). Konflik yang terjadi diakibatkan adanya perbedaan kepentingan antara pemilik dan manajer. Konflik tersebut dikenal dengan konflik keagenan. Jensen dan Meckling (1976) menyatakan bahwa salah satu upaya yang dilakukan untuk meredam konflik keagenan adalah dengan mengawasi perilaku manajer (agent). Ada dua mekanisme yang digunakan untuk menyelaraskan kepentingan antara pemilik dengan manajer. Pertama, dengan mengadopsi fungsi audit dan mekanisme lain dalam tata kelola perusahaan yang dapat menyelaraskan kepentingan agent dengan kepentingan principal. Kedua, menyediakan insentif dan penghargaan untuk agent sehingga agent dapat bertindak sesuai dengan kepentingan principal. Penelitian ini menggunakan mekanisme yang pertama, yaitu mekanisme pengawasan. Keberadaan dewan komisaris dan komite merupakan mekanisme yang digunakan untuk aktivitas pengendalian dan pengawasan dalam perusahaan.

Keberadaan komisaris yang independen dapat memberikan kontribusi yang substansial untuk keputusan yang penting. Kehadiran komisaris independen dapat memberikan investor keyakinan tambahan mengenai kinerja perusahaan (Elshandidy dan Neri, 2015). Oleh karena itu, pengangkatan komisaris independen akan memiliki efek positif bagi perusahaan. Komposisi dewan yang terdiri dari komisaris independen dengan jumlah yang lebih banyak akan cenderung mendorong pengungkapan terkait kinerja yang berkualitas tinggi (Barako et al., 2006). Selain itu, adanya komisaris independen di dewan, semakin besar kemungkinan dewan dapat mengidentifikasi risiko yang relevan dan meningkatkan kualitas pengungkapan manajemen risiko (Abraham dan Cox, 2007; Barakat dan Hussainey, 2013; Ntim et al., 2013).

H1: Keberadaan komisaris independen dalam perusahaan memiliki pengaruh yang positif terhadap pengungkapan risiko.

Latar belakang pendidikan formal anggota dewan komisaris merupakan karakteristik yang dapat mempengaruhi kemampuannya dalam mengambil keputusan dan menjalankan fungsi pengawasan (Buckby et al., 2015; Allini et al., 2016). Latar belakang pendidikan formal dalam bidang ekonomi dan bisnis tentunya dapat mempengaruhi keahlian ataupun profesionalisme dewan komisaris dalam mengidentifikasi masalah atau potensi risiko yang relevan dan spesifik yang dapat mempengaruhi kinerja perusahaan (Mangena dan Pike, 2005).

H2: Dewan komisaris yang memiliki latar belakang pendidikan ekonomi, bisnis dan hukum memiliki pengaruh yang positif terhadap pengungkapan risiko.

Peran pengawasan pada komite audit telah diidentifikasi sebagai mekanisme pemantauan yang efektif yang membantu mengurangi biaya agensi dan asimetri informasi antara manajemen dan pemegang saham (Allegrini dan Greco, 2013). Selain itu, keberadaan komite audit memiliki fungsi utama yaitu sebagai pihak yang menjaga kualitas pelaporan keuangan (Haniffa dan Cooke, 2002; Eng dan Mak, 2003; Barakat dan Hussainey, 2013). Selain itu, fungsi utama lainnya adalah menjaga keseimbangan dan melindungi kepentingan pemegang saham, khususnya terhadap potensi risiko yang akan terjadi (Mangena dan Pike, 2005). Zhang et al. (2013) menemukan bahwa komite audit berpengaruh terhadap pengungkapan risiko.

H3: Keberadaan komite audit memiliki pengaruh yang positif terhadap pengungkapan risiko.

Seorang anggota komite audit harus paham tentang keuangan dan harus memiliki pemahaman tentang industri tempat entitas beroperasi (Mangena dan Pike, 2005). Dengan latar belakang kompetensi akuntansi yang dimiliki, kebe radaan komite audit diharapkan dapat mengadopsi standar akuntabilitas dan 
Karakteristik

Dewan

Komisaris...

118 membantu dalam pengendalian dan pengawasan perusahaan secara efektif (Allegrini dan Greco, 2013; Buckby et al., 2015).

H4: Keahlian komite audit memiliki pengaruh yang positif terhadap pengungkapan risiko.

Komite Manajemen Risiko (KMR) merupakan salah satu unsur penting dalam pengelolaan manajemen risiko perusahaan (Al-Hadi et al., 2016). Tugas dan wewenang RMC adalah mempertimbangkan strategi, mengevaluasi manajemen risiko, dan memastikan bahwa perusahaan telah memenuhi hukum dan peraturan yang berlaku (Subramaniam et al., 2009). Selain itu, KMR dibentuk sebagai mekanisme untuk memperbaiki pengungkapan, khususnya yang terkait risiko (Al-Hadi et al., 2016). KMR dapat mengurangi konflik agensi antara manajer pemegang saham, karena KMR tidak memiliki hubungan dengan para manajer atau pemegang saham, hal ini karena keberadaan KMR dapat memberikan penilaian yang benar-benar objektif mengenai risiko yang dihadapi oleh perusahaan (Subramaniam et al., 2009).

H5: Keberadaan komite manajemen risiko memilik pengaruh yang positif terhadap pengungkapan risiko.

\section{METODE PENELITIAN}

Penelitian ini menggunakan pendekatan kausal (sebab-akibat). Desain penelitian kausal digunakan untuk menguji hubungan sebab dan akibat dari beberapa variabel. Populasi dalam penelitian ini adalah perusahaan yang terdaftar di Bursa Efek Indonesia (BEI) periode tahun 2014-2016. Pemilihan periode tersebut didasarkan pada tahun terbaru pada saat pengumpulan data penelitian ini dilakukan. Pemilihan teknik dalam penelitian ini menggunakan teknik sampel bertujuan ( $p u r$ posive sampling). Kriteria pengambilan sampel dapat dilihat di Tabel 1.

\begin{tabular}{lcc}
\hline \multicolumn{1}{c}{ Kriteria } & $\begin{array}{c}\text { Jumlah } \\
\text { Perusahaan }\end{array}$ \\
\hline - $\begin{array}{l}\text { Perusahaan terdaftar di Bursa Efek Indonesia (BEI) } \\
\text { selama periode 2014-2016. }\end{array}$ & 1573 \\
- Perusahaan keuangan terdaftar dalam Bursa Efek & $(243)$ \\
$\begin{array}{l}\text { Indonesia (BEI) selama periode 2014-2016. } \\
\text { - Perusahaan non-keuangan terdaftar dalam Bursa Efek }\end{array}$ & 1330 \\
$\begin{array}{l}\text { Indonesia (BEI) selama periode 2014-2016 } \\
\text { Perusahaan secara konsisten mengungkapkan informasi 5 } \\
\text { tipe risiko sejak 2014 }\end{array}$ & 168 \\
\hline Persentase sampel & $12.6 \%$ \\
\hline
\end{tabular}

Dalam penelitian ini, tingkat pengungkapan risiko dihitung dengan menggunakan metode analisis kandungan (content analysis). Metode content analysis sering digunakan dalam penelitian-penelitian yang telah dilakukan sebelumnya (Abraham dan Cox, 2007; Amran et al., 2009; Abraham dan Shrives, 2014; Achmad et al., 2017). Tabel 2 menyajikan item-item pengungkapan yang digunakan untuk mengukur pengungkapan risiko berdasarkan sumber Linsley dan Shrives (2006) dikembangkan dan digunakan oleh Amran et al. (2009) dan Achmad et al. (2017). 


\begin{tabular}{|c|c|}
\hline Kategori Risiko & Komponen \\
\hline Risiko Keuangan & $\begin{array}{l}\text { (1) tingkat suku bunga (2) tingkat kurs (3) komoditas } \\
\text { (4) likuiditas (5) kredit }\end{array}$ \\
\hline Risiko Operasional & $\begin{array}{l}\text { (6) kepuasan pelanggan (7) pengembangaan produk (8) } \\
\text { kinerja dan efisiensi (9) sumber (10) tingkat keusangan } \\
\text { persediaan (11) kegagalan produk/jasa (12) lingkungan } \\
\text { (13) keselamatan kerja (14) penurunan merek produk }\end{array}$ \\
\hline Risiko Pemberdayaan & $\begin{array}{l}\text { (15) kepemimpinan dan manajemen (16) outsourcing (17) } \\
\text { insentif kinerja(18) perubahan ketersediaan (19) } \\
\text { komunikasi }\end{array}$ \\
\hline $\begin{array}{l}\text { Risiko Pemrosesan } \\
\text { Teknologi dan } \\
\text { Informasi }\end{array}$ & (20) integritas (21) akses (22) ketersedian infrastruktur \\
\hline Risiko Integritas & $\begin{array}{l}\text { (23) kebijakan manajemen risiko (24) kecurangan } \\
\text { manajemen dan karyawan (25) tindakan ilegal (26) } \\
\text { reputasi }\end{array}$ \\
\hline Risiko Strategik & $\begin{array}{l}\text { (27) pemindaian lingkungan (28) industri (29) portfolio } \\
\text { bisnis (30) pesaing (31) penentuan harga (32) Valuasi ( } 33) \\
\text { perencanaan (34) siklus hidup (35) pengukuran kinerja } \\
\text { (36) pengaturan (37) kedaulatan dan politik }\end{array}$ \\
\hline \multicolumn{2}{|c|}{$\begin{array}{l}\text { Pengukuran menggunakan pendekatan indek tidak berbobot (unweighted), skor } \\
\text { diberikan jika perusahaan mengungkapan item dan } 0 \text { jika tidak. } \\
\text { Indeks Pengungkapan Risiko = jumlah item yang diungkapkan dibagi dengan total } \\
\text { item pengungkapan ( } 37 \text { item) }\end{array}$} \\
\hline
\end{tabular}

Tabel 2.

Item Pengukuran Pengungkapan Risiko

Variabel independen dalam penelitian ini adalah dewan komisaris independen, keahlian dewan komisaris, komite audit, keahlian komite audit dan komite manajemen risiko. Sedangkan variabel kontrol yang digunakan adalah auditor eksternal, leverage, market to book ratio. Variabel dewan komisaris independen dalam penelitian ini diukur dengan menggunakan proporsi jumlah anggota dewan komisaris yang independen terhadap total anggota dewan komisaris. Untuk variabel keahlian dewan komisaris diproksikan dengan proporsi anggota dewan komisaris yang memiliki latar belakang pendidikan formal dalam salah satu bidang seperti ekonomi, bisnis, akuntansi, keuangan dan hukum terhadap jumlah total dewan komisaris. Variabel komite audit diukur dengan jumlah komite audit. Variabel keahlian komite audit diukur dengan proporsi anggota komite audit yang memiliki latar belakang pendidikan formal dalam bidang ekonomi, bisnis, akuntansi, keuangan dan hukum terhadap jumlah total anggota komite audit. Variabel keberadaan komite manajemen risiko diukur dengan variabel dummy. 1 jika perusahaan memiliki komite manajemen risiko dan 0 jika tidak. Untuk variabel kontrol audit eksternal menggunakan variabel dummy, 1 diberikan jika perusahaan diaudit oleh KAP Big-Four dan 0 untuk yang diaudit oleh non Big-Four. Variabel leverage diukur dengan menggunakan rasio utang terhadap aset (total kewajiban/total aset). Variabel market to book ratio diukur dengan membagi nilai kapitalisasi pasar dengan nilai buku ekuitas. Model statistik penelitian ini dapat dinyatakan dengan persamaan:

$\mathrm{PR}=\alpha+\beta_{1} \mathrm{DKI}+\beta_{2} \mathrm{KDK}+\beta_{3} \mathrm{KA}+\beta_{4} \mathrm{KKA}+\beta_{5} \mathrm{KMR}+\beta_{6} \mathrm{AE}+\beta_{7} \mathrm{LEV}+\beta_{8} \mathrm{MTB}+\varepsilon$

Keterangan:

Variabel Dependen $=\mathrm{PR}=$ pengungkapan risiko

Variabel Independen: DKI = Dewan Komisaris Indonesia; KDK = Keahlian Dewan Komisaris; KA = Komite Audit; KKA = Keahlian Komite Audit; KMR = Komite Manajemen Risiko

Variabel Kontrol: $\mathrm{AE}=$ Auditor Eksternal; $\mathrm{LEV}=$ Leverage; $\mathrm{MTB}=$ Market to Book Ratio 
Karakteristik

Dewan

Komisaris...

120

\section{HASIL DAN PEMBAHASAN}

Tabel 3 menyajikan statistik deskriptif variabel penelitian. Berdasarkan Tabel 3 dapat disimpulkan bahwa nilai rata-rata variabel dewan komisaris independen 0.40 , dengan nilai minimum 0.25 dan nilai maksimum 0.67 . Hal ini mengindikasikan bahwa masih ada perusahaan yang belum memenuhi ketentuan BEI yaitu mempunyai jumlah dewan komisaris independen sekurang-kurangnya 30\% dari jumlah seluruh anggota komisaris. Untuk variabel komite audit, nilai rataratanya adalah 0.37 , dengan nilai minimum 0.30 dan nilai maksimum 0.75 . Hasil ini menjelaskan bahwa perusahaan telah memiliki jumlah komite audit sesuai dengan ketentuan BEI, yaitu sekurang-kurangnya 30\%. Variabel leverage memiliki rata-rata 0.48 , nilai minimum 0.06 dan nilai maksimum 1.63 . Hal ini menunjukkan bahwa rata-rata perusahaan mempunyai tingkat hutang yang relatif tinggi. Untuk variabel kinerja keuangan lainnya, market to book ratio memiliki rata-rata 1.4187, nilai minimum -2.85 dan nilai maksimum 22.11. Hal ini menunjukan bahwa ratarata perusahaan sampel memiliki kapitalisasi pasar relatif tinggi, sebesar $1.41 \mathrm{kali}$ dari nilai buku ekuitasnya.

\begin{tabular}{lccccc}
\hline Variabel & $\mathrm{N}$ & Minimum & Maksimum & Rerata & \multicolumn{1}{c}{ SD } \\
\hline PR & 168 & .14 & .78 & .50 & .12 \\
DKI & 168 & .25 & .67 & .40 & .08 \\
KDK & 168 & .17 & 1.00 & .54 & .22 \\
KA & 168 & .30 & .75 & .37 & .11 \\
KKA & 168 & .33 & 1.00 & .81 & .23 \\
KMR & 168 & .00 & 1.00 & .07 & .25 \\
AE & 168 & .00 & 1.00 & .41 & .49 \\
LEV & 168 & .06 & 1.63 & .48 & .26 \\
MTB & 168 & -2.85 & 22.11 & 1.41 & 2.61 \\
\hline Catatan: Variabel Dependen = PR = pengungkapan risiko; Variabel Independen: DKI = Dewan \\
Komisaris Indonesia; KDK = Keahlian Dewan Komisaris; KA = Komite Audit; KKA = Keahlian \\
Komite Audit; KMR = Komite Manajemen Risiko; AE = Auditor Eksternal; LEV = Leverage; MTB = \\
Market to Book Ratio \\
\multicolumn{5}{r}{} \\
\hline
\end{tabular}

Berdasarkan Tabel 4 dapat disimpulkan bahwa model penelitian memenuhi asumsi klasik untuk menggunakan analisis regresi berganda. Hasil pengujian OneSample Kolmogorv-Smirnov menunjukkan distribusi residual adalah normal. Untuk pengujian heterosedastisitas, seluruh variabel independen memiliki $p$-value $>0.05$ dan model penelitian ini juga bebas dari masalah multikolinearitas, seluruh nilai VIF variabel independen lebih besar dari 0.05 .

\begin{tabular}{|c|c|c|c|c|c|c|c|c|}
\hline \multirow{2}{*}{ Variabel } & \multirow[t]{2}{*}{ Prediksi } & \multirow{2}{*}{$\begin{array}{c}\text { Koefisien } \\
\text { regresi }\end{array}$} & \multirow[t]{2}{*}{$\mathrm{t}$} & \multirow{2}{*}{$\begin{array}{c}\mathrm{p}^{-} \\
\text {value }\end{array}$} & \multicolumn{2}{|c|}{ Multikolinieritas } & \multicolumn{2}{|c|}{ Heterokedastisitas } \\
\hline & & & & & Tolerance & VIF & $\mathrm{t}$ & $\mathrm{p}^{\text {-value }}$ \\
\hline Konstanta & & .609 & 8.732 & .000 & - & - & & \\
\hline DKI & + & -.295 & $\begin{array}{c}- \\
.2 .858\end{array}$ & .005 & .887 & 1.128 & -2.033 & .454 \\
\hline $\mathrm{KDK}$ & + & -.047 & $\begin{array}{c}- \\
.1 .202\end{array}$ & .231 & .910 & 1.098 & .470 & .639 \\
\hline $\mathrm{KA}$ & + & -.006 & -.072 & .943 & .896 & 1.116 & 1.763 & .639 \\
\hline KKA & + & .054 & 1.458 & .147 & .914 & 1.094 & .261 & .080 \\
\hline KMR & + & .133 & 3.802 & .000 & .849 & 1.177 & 1.474 & .143 \\
\hline $\mathrm{AE}$ & + & .104 & 5.800 & .000 & .900 & 1.112 & 1.346 & .725 \\
\hline LEV & - & -.089 & -2.594 & .010 & .821 & 1.217 & 1.823 & .327 \\
\hline MTB & + & .014 & 4.256 & .000 & .895 & 1.118 & 1.224 & .526 \\
\hline
\end{tabular}

Uji Auto Korelasi: $\mathrm{D}_{\mathrm{U}}=1.577 ; \mathrm{DW}=2.183 ; 4-\mathrm{D}_{\mathrm{U}}=2.423$. Kesimpulan: tidak ada auto korelasi.

Uji One-Sample Kolmogorov-Smirnov p-value $=0.200$

Tabel 4.

Adjusted $\mathrm{R}^{2}=.275 ; \mathrm{F}=7.311 ; \mathrm{p}^{-}$value $=.000 ; \mathrm{N}=168$

Hasil Pengujian

Catatan: Variabel Dependen = PR = pengungkapan risiko; Variabel Independen: DKI = Dewan Komisaris Indonesia;

$\mathrm{KDK}=$ Keahlian Dewan Komisaris; KA = Komite Audit; KKA = Keahlian Komite Audit; KMR = Komite Manajemen

Risiko; AE = Auditor Eksternal; LEV = Leverage; MTB = Market to Book Ratio 
Tabel 4 juga menyajikan hasil pengujian regresi. Hasil analisis menunjukkan bahwa variabel keberadaan dewan komisaris independen memiliki pengaruh yang signifikan terhadap pengungkapan risiko $\left(t=-2.858\right.$, $\mathrm{p}^{-}$value $\left.=0.00\right)$, namun arah hubungan negatif. Dengan demikian hipotesis 1 tidak didukung. Hasil ini berlawanan dengan Barakat dan Hussainey (2013), Abraham dan Cox (2007). Namun hasil ini konsisten dengan temuan Allegrini dan Greco (2013), Domínguez-Rodriguez dan Noguera-Gámez (2014), dan Achmad et al. (2017). Temuan ini mengindikasikan bahwa independensi dari dewan komisaris belum menjamin bahwa perusahaan untuk mengungkapkan informasi risiko lebih banyak. Kemungkinan lainnya adalah bahwa fungsi pengawasan oleh dewan komisaris belum berjalan sepenuhnya. Hal ini disebabkan pengangkatan dewan komisaris independen diduga hanya sekedar memenuhi regulasi dari BEI, bahwa setiap perusahan publik harus memiliki komisaris independen (Achmad et al., 2017).

Demikian juga halnya untuk variabel keahlian dewan komisaris, komite audit, serta keahlian komite audit, hasil analisis menunjukkan bahwa variabel-variabel tersebut tidak berpengaruh signifikan terhadap pengungkapan risiko $(\mathrm{t}=-1.202$ dan $\mathrm{p}^{\text {-value }}=0.231 ; \mathrm{t}=-0.072$ dan $\mathrm{p}^{\text {-value }}=0.943 ; \mathrm{t}=1.458$ dan $\left.\mathrm{p}^{\text {-value }}=0.147\right)$. Dengan demikian hipotesis 2, 3, dan 4 juga tidak berhasil didukung. Hasil temuan ini mengindikasikan bahwa latar belakang pendidikan dan keahlian dewan komisaris dan komite audit dalam bidang ekonomi, keuangan dan bisnis belum sepenuhnya menjadi pendorong untuk meningkatkan pengungkapan risiko. Hasil penelitian ini berlawanan dengan temuan (Allini et al., 2016), namun konsisten dengan penelitian (Buckby et al., 2015; Martikainen et al., 2015). Secara teori, semakin ahli seorang dewan komisaris mapun komite audit semakin tinggi kapabilitasnya untuk mengidentifikasi permasalahan-permasalahan komplek yang terjadi dalam perusahaan, termasuk mengidentifikasi luas dan cakupan potensi risiko yang akan terjadi.

Untuk hipotesis 5, hasil analisis menunjukkan bahwa variabel keberadaan manajemen risiko memiliki pengaruh yang signifikan dan positif terhadap pengungkapan risiko perusahaan $\left(\mathrm{t}=3.802\right.$ dan $\mathrm{p}^{-}$-value $\left.=0.000\right)$. Hasil ini menunjukkan bahwa keberadaan KMR memainkan peran penting dalam mendorong perusahaan untuk mengungkapkan risiko. Selain itu, keberadaan KMR juga berperan untuk meningkatkan minat pemegang saham dalam melakukan pengawasan dan pengandalian melalui pengungkapan informasi risiko. Untuk variabel kontrol, hasil analisis menunjukkan bahwa auditor eksternal (Big-Four), tingkat leverage perusahaan, dan kapitalisasi pasar (market to book ratio) berpengaruh signifikan terhadap pengungkapan risiko. Hubungan positif antara keberadaan auditor Big-Four terhadap pengungkapan risiko menunjukkan bahwa perusahaan yang diaudit oleh auditor Big-Four cenderung untuk lebih taat asas terhadap regulasi dan peraturan sehingga mendorong mereka untuk mengungkapkan adanya potensi risiko yang dihadapi perusahaan. Perusahaan nonkeuangan yang memiliki tingkat leverage yang tinggi mengindikasikan bahwa mereka memiliki tingkat risiko yang lebih besar dibandingkan dengan perusahaan non-keuangan lainnya yang memiliki tingkat leverage yang rendah. Perusahaan dengan tingkat leverage yang tinggi tentuknya akan mendapat perhatian yang lebih besar dari pemegang saham terkait dengan potensi risiko. Salah satu mekanisme untuk mengurangi tekanan tersebut, perusahaan akan mengungkapkan lebih banyak informasi risiko kepada pemegang saham. Kapitalisasi pasar yang tinggi menunjukkan bahwa perusahaan memiliki kinerja keuangan yang baik. Tingkat kinerja yang tinggi mengindikasikan bahwa tingkat risiko yang dihadapi perusahaan lebih rendah, sehingga tekanan dari pemegang saham menjadi lebih rendah.

\section{SIMPULAN}

Berdasarkan pembahasan pada bagian sebelumnya, dapat simpulkan: Pertama, variabel dewan komisaris independen berpengaruh negatif terhadap 
pengungkapan risiko perusahaan; variabel keahlian dewan komisaris tidak berpengaruh terhadap pengungkapan risiko perusahaan; variabel komite audit tidak berpengaruh terhadap pengungkapan risiko; variabel keahlian komite audit tidak berpengaruh terhadap pengungkapan risiko. Kedua, variabel komite manajemen risiko berpengaruh terhadap pengungkapan risiko perusahaan. Hasil penelitian ini juga menunjukkan bahwa seluruh variabel kontrol (auditor eksternal, leverage, dan market to book ratio) berpengaruh terhadap pengungkapan risiko.

Temuan dari penelitian ini memberikan implikasi terhadap pengembangan literatur dan praktik dibidang bisnis dan akuntansi. Berdasarkan perspektif teori agensi, temuan penelitian ini mengindikasikan bahwa perusahaan mengungkapkan tambahan informasi terkait risiko kemungkinan untuk meyakinkan pemegang saham bahwa mereka sudah mengoptimalkan peran mereka dalam meningkatkan kinerja. Selain itu, hasil penelitian ini juga mengindikasikan bahwa keefektifan pengungkapan risiko perusahaan belum sepenuhnya tercermin dari efektivitas karakteristik dewan komisaris dan komite audit. Implikasi praktis yang disumbangkan dari hasil penelitian ini adalah bahwa regulator perlu lebih dalam untuk memahami faktor-faktor yang mendorong perusahaan untuk mengungkapkan informasi risiko. Dengan membuat kebijakan yang mengharuskan seluruh perusahaan untuk memiliki komite manajeme risiko di perusahaan, kemungkinan akan memberikan hasil yang lebih signifikan dalam usaha untuk mendorong transparansi dalam aspek risiko perusahaan.

Penelitian ini memiliki keterbatasan-keterbatasan. Pertama, penelitian ini hanya menggunakan perusahaan non keuangan yang terdaftar di Bursa Efek Indonesia dan terbatas pada periode 2014-2016. Kedua, hasil penelitian ini belum sepenuhnya mendukung peran implementasi tata kelola yang direpresentasikan oleh keberadaan dan keahlian dewan komisaris dan komite dalam mendorong perusahaan untuk lebih banyak mengungkapkan informasi terkait risiko. Penelitian selanjutnya diharapkan dapat memperbaiki kelemahan penelitian ini dengan mempertimbangkan proksi tambahan dari variabel tata kelola perusahaan seperti penggunaan skor atau indek, sehingga dapat merepresentasikan seluruh elemen dari praktik tata kelola perusahaan.

\section{DAFTAR PUSTAKA}

Abraham, S. and Cox, P. (2007) 'Analysing the determinants of narrative risk information in uk ftse 100 annual reports', The British Accounting Review, Vol. 39, No. 3.

Abraham, S. and Shrives, P.J. (2014) 'Improving the relevance of risk factor disclosure in corporate annual reports', The British Accounting Review, Vol. 46, No. 1.

Achmad, T., Faisal, F. and Oktarina, M. (2017) 'Factors influencing voluntary corporate risk disclosure practices by indonesian companies', Corporate Ownership \& Control, Vol. 14, No. 3.

Al-Hadi, A., Hasan, M.M. and Habib, A. (2016) 'Risk committee, firm life cycle, and market risk disclosures', Corporate Governance: An International Review, Vol. 24, No. 2.

Al-Maghzom, A., Hussainey, K. and Aly, D. (2016) 'Corporate governance and risk disclosure: Evidence from saudi arabia', Corporate Ownership and Control Journal, Vol. 13, No. 2.

Allegrini, M. and Greco, G. (2013) 'Corporate boards, audit committees and voluntary disclosure: Evidence from italian listed companies', Journal of Management \& Governance, Vol. 17,No. 1.

Allini, A., Manes Rossi, F. and Hussainey, K. (2016) 'The board's role in risk disclosure: An exploratory study of italian listed state-owned enterprises', Public Money \& Management, Vol. 36,No. 2. 
Amran, A., Bin, A.M.R. and Hasan, B.C.H.M. (2009) 'Risk reporting: An exploratory study on risk management disclosure in malaysia annual reports', Managerial Auditing Journal, Vol. 24, No. 1.

Barakat, A. and Hussainey, K. (2013) 'Bank governance, regulation, supervision, and risk reporting: Evidence from operational risk disclosures in european banks', International Review of Financial Analysis, Vol. 30.

Barako, D.G., Hancock, P. and Izan, H.Y. (2006) 'Factors influencing voluntary corporate disclosure by kenyan companies', Corporate Governance: An International Review, Vol.14, No. 2.

Beretta, S. and Bozzolan, S. (2004) 'A framework for the analysis of firm risk communication', The International Journal of Accounting, Vol. 39, No. 3.

Buckby, S., Gallery, G. and Ma, J. (2015) 'An analysis of risk management disclosures: Australian evidence', Managerial Auditing Journal, Vol. 30, No. 8/9.

Chang, C.-S., Yu, S.-W. and Hung, C.-H. (2015) 'Firm risk and performance: The role of corporate governance', Review of Managerial Science, Vol. 9, No. 1.

Domínguez-Rodriguez, L. and Noguera-Gámez, L.C. (2014) 'Corporate reporting on risks: Evidence from spanish companies', Revista de Contabilidad, Vol. 17, No. 2.

Elshandidy, T. and Neri, L. (2015) 'Corporate governance, risk disclosure practices, and market liquidity: Comparative evidence from the uk and italy', Corporate Governance: An International Review, Vol. 23,No. 4.

Eng, L.L. and Mak, Y.T. (2003) 'Corporate governance and voluntary disclosure', Journal of Accounting and Public Policy Vol. 22, No. 4.

Gray, S., Harymawan, I. and Nowland, J. (2014) 'Political and government con' nections on corporate boards in australia: Good for business?', Australian Journal of Management, Vol. 41, No. 1.

Haniffa, R.M. and Cooke, T.E. (2002) 'Culture, corporate governance and disclosure in malaysian corporations', Abacus, Vol. 38 No. 3.

Htay, S.N.N., Rashid, H.M.A., Adnan, M.A. and Mydin, M.A.K. (2011) 'Corporate governance and risk management information disclosure in malaysian listed banks: Panel data analysis', International Review of Business Research Papers, Vol. 7, No.4.

Jensen, M.C. and Meckling, W.H. (1976) 'Theory of the firm: Managerial behaviour, agency costs and ownership structure', Journal of Financial Economics, Vol. 3, No. 4.

Linsley, P.M. and Shrives, P.J. (2006) 'Risk reporting: A study of risk disclosures in the annual reports of uk companies', The British Accounting Review, Vol. 38, No. 4.

Mangena, M. and Pike, R. (2005) 'The effect of audit committee shareholding, financial expertise and size on interim financial disclosures', Accounting and Business Research, Vol. 35, No. 4.

Martikainen, M., Othmar M. Lehner, P., Kinnunen, J., Miihkinen, A. and Troberg, P. (2015) 'Board's financial incentives, competence, and firm risk disclosure', Journal of Applied Accounting Research, Vol. 16, No. 3.

Ntim, C.G., Lindop, S. and Thomas, D.A. (2013) 'Corporate governance and risk reporting in south africa: A study of corporate risk disclosures in the pre- and post-2007/2008 global financial crisis periods', International Review of Financial Analysis, Vol. 30.

Samaha, K., Khlif, H. and Hussainey, K. (2015) 'The impact of board and audit committee characteristics on voluntary disclosure: A meta-analysis', Journal of International Accounting, Auditing and Taxation, Vol. 24.

Subramaniam, N., McManus, L. and Zhang, J. (2009) 'Corporate governance, firm characteristics and risk management committee formation in australian com' panies', Managerial Auditing Journal, Vol. 24. 
Karakteristik Taylor, G., Tower, G. and Neilson, J. (2010) 'Corporate communication of financial Dewan risk', Accounting \& Finance, Vol. 50, No. 2.

Komisaris...

Watts, R.L. and Zimmerman, J.L. (1983) 'Agency problems, auditing, and the theory of the firm: Some evidence', The Journal of Law and Economics, Vol. 26, No. 3.

Zhang, X., Taylor, D., Qu, W. and Oliver, J. (2013) 'Corporate risk disclosures: Influence of institutional shareholders and audit committee', Corporate $\mathrm{OWn}^{-}$ ership \& Control, Vol. 10, No. 4. 